\title{
Viability of using olive stones as lightweight aggregate in construction mortars
}

\section{Viabilidad del uso de huesos de aceituna como agregado ligero en morteros para la construcción}

Mercedes del Río Merino (Main and Corresponding Author)

Escuela Técnica Superior de Edificación (Universidad Politécnica de Madrid)

Avenida Juan de Herrera 6. 28040 Madrid (Spain)

mercedes.delrio@upm.es

\section{Javier Guijarro Rodríguez}

Escuela Técnica Superior de Edificación (Universidad Politécnica de Madrid)

Avenida Juan de Herrera 6. 28040 Madrid (Spain)

javier.guijarro@alumnos.upm.es

\section{Francisco Fernández Martínez}

Escuela Técnica Superior de Diseño Industrial (Universidad Politécnica de Madrid)

Avenida Ramiro de Maeztu 7. 28040 Madrid (Spain)

francisco.fernandezm@upm.es

Jaime Santa Cruz Astorqui

Escuela Técnica Superior de Edificación (Universidad Politécnica de Madrid)

Avenida Juan de Herrera 6. 28040 Madrid (Spain)

jaime.santacruz@upm.es

Manuscript Code: 781

Date of Acceptance/Reception: 29.11.2017/21.06.2016

DOI: 10.7764/RDLC.16.3.431

\section{Abstract}

This article presents the results of a research project which studies the feasibility of substituting -in cement mortars- the most commonly used lightweight aggregates in Spanish building constructions (i.e. expanded clay), by waste from the olive industry. Spain is the world's largest producer of olive oil and olives, being therefore the main producer of olive-stone waste. These olive stones are currently used as biomass. To determine the viability of substitution, an experimental plan was designed. The objective of this plan was to add three different olive stone formats (entire, crushed and calcined) in cement mortars, using similar percentages additions as the ones used by the manufacturers of lightweight expanded clay mortars. From the results obtained it can be concluded that it is feasible to replace expanded clay by olive stones waste, obtaining mortars with lower densities, up to $30 \%$, and improved compressive strength, up to $20 \%$ compared to lightweight expanded clay mortars.

Key words: Sustainability, waste, olive stones, lightweight aggregate, cement mortar.

Resumen

Este artículo presenta los resultados de un proyecto de investigación que estudia la posibilidad de sustituir, en morteros de cemento, los agregados ligeros que se utilizan de forma más habitual en España en la construcción de edificios, (por ejemplo la arcilla expandida), por residuos de la industria de la aceituna. España es el país del mundo que produce mayor cantidad de aceite de oliva y aceitunas, siendo por tanto el principal productor de residuo de hueso de aceituna. Esos huesos de aceituna se utilizan en la actualidad como biomasa. Para determinar la viabilidad de sustitución, se diseñó un plan experimental. El objetivo del plan fue añadir en morteros de cemento tres formatos diferentes de huesos de aceituna: huesos enteros, huesos rotos y calcinados, usando similares porcentajes de adición a los utilizados por los fabricantes de morteros aligerados con arcilla expandida. De los resultados se puede concluir que es posible sustituir los áridos de arcilla expandida por el residuo de huesos de aceituna, obteniendo morteros con densidades más bajas, por encima de un 30\%, y mejorando la resistencia a compresión, por encima de un $20 \%$, sobre morteros aligerados con arcilla expandida.

Palabras clave: Sostenibilidad, residuo, huesos de aceituna, agregado ligero, mortero de cemento.

Introduction

During 2014-2015 the production of the Spanish food industries accounted for 93,396 million euro of which 7\% are from the olive oil sector (Ministerio de Agricultura y Pesca, Alimentación y Medioambiente, 2014). These food industries produce large volumes of waste, both solid and liquid, representing a disposal and potentially environmental pollution problem (Fernández-Bolaños, Rodríguez, Rodríguez, Guillén \& Jiménez, 2006). One of the most typical Spanish industries is the olive oil industry, which represents more than a $5 \%$ of the agricultural companies. 
There are three main producer countries of olive oil in the world: Spain, Italy and Greece, but Spain is the largest olive oil producer and exporter in the world, producing about of $75 \%$ of the total production of olive oil in the world (European Commission, Directorate-General for Agriculture and Rural Development, 2012), with an average production of 1,300,000 tons and in the period between 2013-2014 1,780,000 tons Ministerio de Agricultura y Pesca, Alimentación y Medioambiente, 2015). This production generated a large amount of by-products, such as (Fernández-Bolaños et al., 2006):

- Olive mill pomace: 0.2 - 0.8 tons of this waste is obtained per ton of processed olive oil. This product can be used for the manufacture of olive pomace or for electricity production.

- Olive tree pruning: this waste is burned or left in the ground itself, with the risk of fire.

- Olive pits: represents $15 \%$ of the whole olive. It should be distinguished between the olive pits generated in the industries dressing and olive oil production.

Several research groups have been working on the alternative use of these organic wastes and the recovery of valuable substances.

In the case of olive pits, they are used for combustion of boilers of the olive industry, as well as in other sectors such as ceramic, farms, etc. However, the technology has experienced a breakthrough and nowadays imported equipment with very high output and low emissions are used. Also, olive pits are being used in the domestic sector as it is cheaper than other fuels with similar properties, as the wooden pellets. Unlike fossil fuels, which increase the $\mathrm{CO}_{2}$ levels in the atmosphere, the carbon dioxide emitted by burning olive pits is fixed by the olive crop cycle. However, the calorific value (kWh) of olive pits is about seven times lower than heating oil, but has the following drawbacks:

- Difficulty in distributing small quantities for detached houses.

- Ash production and collection after combustion. There is a lack of regulation considering the management and treatment of these wastes.

- Need for special biomass facilities.

But olive pits have excellent fuel characteristics, due to its high calorific around 4,500 kcal/ $\mathrm{kg}$, being therefore, very suitable for construction materials with high thermal properties for both industrial and domestic residential buildings.

On the other hand, since ancient times, lightweight aggregates (such as volcanic rocks) are being used to reduce the weight of different building conglomerates (Del Río, Santa Cruz \& Gonzalez, 2005). Currently, in Spain, expanded clay is one of the most commonly used lightweight aggregate to reduce the density of mortars and concretes. Using expanded clay in mortars and concretes, not only helps to achieve lighter materials -allowing to build more stories using the same foundation - , but also improves their thermal and acoustic properties. The first buildings that used lightweight concrete using expanded clay were built in the United States after the World War I by the company Haydite (Muñoz, 2015). However, despite the good properties of the expanded clay, this aggregate has an important environmental impact because it needs high temperatures for its manufacture.

Numerous papers, published in scientific journals, were found analysing different methods to reduce the weight of mortars and concretes. These studies used different industrial wastes as aggregates, such as expanded polystyrene (Miled, Le Roy, Sab \& Boula, 2004), rice husk (Arce, 1997), (Valdez \& Suarez, 2010) or palm shell waste (Shafigh, Jumaat, Mahmud \& Hamid, 2012). In all these studies significant reductions in density were achieved when aggregate was substituted by waste in mortars or concretes (this reduction varies depending on the density of the waste). However, generally, this decrease in density was followed by significant mechanical strength reductions of the compounds.

The study presented in this paper continues with this research line, analysing the feasibility of using olive stones as lightweight aggregate in construction mortars, replacing the expanded clay currently used in Spain. This would help to achieve mortars with similar characteristics to the traditional ones, but with lower environmental impact. On the other hand, this research would help to recycle an abundant waste generated in Spain that has never been used industrially, introducing it in a new production cycle.

Materials and methods

Three different types of olive stones from Charcolive S.L., have been used:

- Normal olive stones (NoS): stones with a minimum particle size of $10 \mathrm{~mm}$.

- Cleaved olive stones (SCr): stones with a particle size between 1 and $4 \mathrm{~mm}$.

- Calcined olive stones (CaS): stones subjected to a pyrolysis treatment, with a particle size between 4 and $10 \mathrm{~mm}$. 
Also, three types of expanded clays (EC)--sold by Saint-Gobain Weber- were used with similar sizes as those of the olive stones:

- Leca-S type, expanded clay with diameters between 1-4 mm.

- Leca -M, expanded clay with diameters between 4-10 $\mathrm{mm}$.

- Leca-L, expanded clay with diameters up to $10 \mathrm{~mm}$.

The cement used was cement of low heat of hydration, CEM IV / A32.5 from Holcim. Normalized sand supplied by Instituto de Ciencias de la Construcción Eduardo Torroja (IETCC) was used.

To determine the feasibility of adding olive stones as raw material in the production of cement mortars, the following experimental plan was designed and developed:

- Stage 1. Physical characterization of olive stones

- Stage 2. Preparation of mortar specimens and testing

\section{Stage 1. Physical characterization of olive stones}

The following preliminary tests were performed on olive stones and expanded clays:

- Bulk Density (according to UNE-EN_1097-2) was determined by the hydrostatic balance method.

- Particle size distribution (according to UNE-EN_993-1)

Moreover, calcined olive stones (CaS), were tested by the following three techniques:

Real Density. A pycnometer and helium gas, were used. This method determines the voids --with radius smaller than 1 Angstrom-- by the difference between the volume occupied by the gas and the volume displaced by the solid portion of the sample. Therefore, knowing the bulk density and the real density, the volume of pores existing in the sample of solid material, can be determined.

Thermogravimetric analysis. Performed in two stages: first, under nitrogen atmosphere and the second one, under oxygen atmosphere. In the first stage, the amount of organic matter was determined in samples of NoS and CrS, stabilizing the weight of the sample at $600{ }^{\circ} \mathrm{C}$ and disappearing the organic matter. During the second stage CaS was tested. It was observed a variation in the weight of the sample when $600{ }^{\circ} \mathrm{C}$ was reached, due to the combination of carbon with oxygen. Thus, the amount of organic and inorganic matter in olive stones was determined.

Morphological analysis. Performed using a scanning electron microscope (SEM) in order to compare the results from real and bulk density as well as the contact surface between the matrix and olive stones.

\section{Stage 2. Preparation of mortar specimens and testing}

Mortar prismatic specimens of $4 \mathrm{~cm} \times 4 \mathrm{~cm} \times 16 \mathrm{~cm}$ - were prepared using cement and normalized sand.

1. In a first approach to the study, several cement mortar specimens were made replacing all the sand by expanded clay or by the different olive stones studied (Table 1).

Despite the aim of this research was to achieve low-strength mortars, around $2 \mathrm{MPa}$, to be used as fillings; it was observed that mortars made with olive stones (NoS) and ( $\mathrm{SCr}$ ) did not harden due to the lack of water. Therefore, only samples containing calcined olive stones (CaS) were further analysed.

For the mixing process the standard UNE- EN_196-1 was followed with the following modifications: the cement was mixed with water at low speed for 30 seconds, then stopped and lightweight aggregate was added. The process continued, mixing the aggregates at a low speed during the first 30 seconds of the cycle.

2. From the results obtained, a second phase was done in order to make mortar specimens according to Saint Gobain Weber's mortar HL12 (Weber, 2017), but replacing the volume of expanded clay by CaS olive stones. As shown in Table 1, different samples were made following the same water/cement (w/c) ratio as mortar HL12 (0.7) and also higher w/c ratios, needing to add a plasticizer --299N Pozzolith from BASF-- in one of the samples (Table 1). 
Due to the vast amount of fines found in the CaS specimens, another set of specimens were prepared prewashing the olive stones (WaCaS0.7). The WaCaS were dried in an oven until a constant weight before use.

\begin{tabular}{lcccccc}
\multicolumn{7}{c}{ Table 1. Dosage of the mortars analyzed. Source: Self elaboration. } \\
$\begin{array}{l}\text { Mortar } \\
\text { specimens }\end{array}$ & w/c ratio & Cement $(\mathrm{kg})$ & Water $(\mathrm{I})$ & $\begin{array}{c}\text { Sand } \\
(\mathrm{kg})\end{array}$ & $\begin{array}{c}\text { Olive stone/ } \\
\text { Exp. clay } \\
\left(\mathrm{dm}^{3}\right)\end{array}$ & $\begin{array}{c}\text { Plasticizer } \\
\text { Cement/ }\end{array}$ \\
\hline HL12 & 0.7 & 0.320 & 0.225 & 0.689 & 0.786 & -- \\
& & & & & $(\mathrm{EC})$ & - \\
CaS-0.7 & 0.7 & 0.320 & 0.225 & 0.689 & 0.786 & - \\
CaS0.7P & 0.7 & 0.320 & 0.225 & 0.689 & 0.786 & $1.2 \%$ \\
WaCaS-0.7 & 0.7 & 0.320 & 0.225 & 0.689 & 0.786 & - \\
CaS-0.75 & 0.75 & 0.320 & 0.225 & 0.689 & 0.786 & - \\
CaS-0.8 & 0.8 & 0.320 & 0.225 & 0.689 & 0.786 & - \\
CaS-0.85 & 0.85 & 0.320 & 0.225 & 0.689 & 0.786 & - \\
\hline
\end{tabular}

At 28 days HL-12 Mortar provided a characteristic resistance of $12 \mathrm{MPa}$ and a density lower than $1500 \mathrm{~kg} / \mathrm{m}^{3}$.

The following tests were made on the mortar specimens:

- Compression test at 7 and 28 days (according to UNE - EN_196-1 standard).

- Mortars' consistency (according to UNE- EN_1015-3 standard).

- Bulk density (according to UNE- EN_1015-10 standard).

- Microstructural analysis (SEM).

Results and discussion

\section{Characterization of olive stones}

Particle size distribution. After the characterization, the particle size homogeneity of the three types of olive stones was observed, being easily compared with expanded clays and proposing the following replacements:

Leca-S expanded clay by cleaved olive stones (SCr); Leca-M expanded clay by calcined olive stones (CaS) and Leca -L clay by normal olive stones (NoS).

On the other hand, it is observed that the mixing water was absorbed by the olive stones NoS and $\mathrm{SCr}$, not allowing the cement hydration due to the organic nature and their wood-like consistency. However, this issue was not observed for olive stones CaS.

Results from the bulk and real density tests are displayed in Table 2.

CaS has a high porosity, as a lower real density is obtained compared to its bulk density. Thus, absorption for CaS is situated around $72 \%$, verifying the high porosity of the material.

\begin{tabular}{lll}
\multicolumn{3}{c}{ Table 2. Results of bulk and real density. Source: Self elaboration. } \\
\hline & Bulk density & Real density \\
\hline Expanded clay & $330.00 \pm 15 \mathrm{~kg} / \mathrm{m}^{3}$ & $29.54 \mathrm{~kg} / \mathrm{m}^{3}$ \\
CaS & $616.00 \mathrm{~kg} / \mathrm{m}^{3}$ & $11.64 \mathrm{~kg} / \mathrm{m}^{3}$ \\
\hline
\end{tabular}

The electron microscope images of the outer, inner and intermediate surfaces of CaS, confirms that it is a porous and homogeneous material with a rough surface on all sides (Figures 1, 2 and 3). 

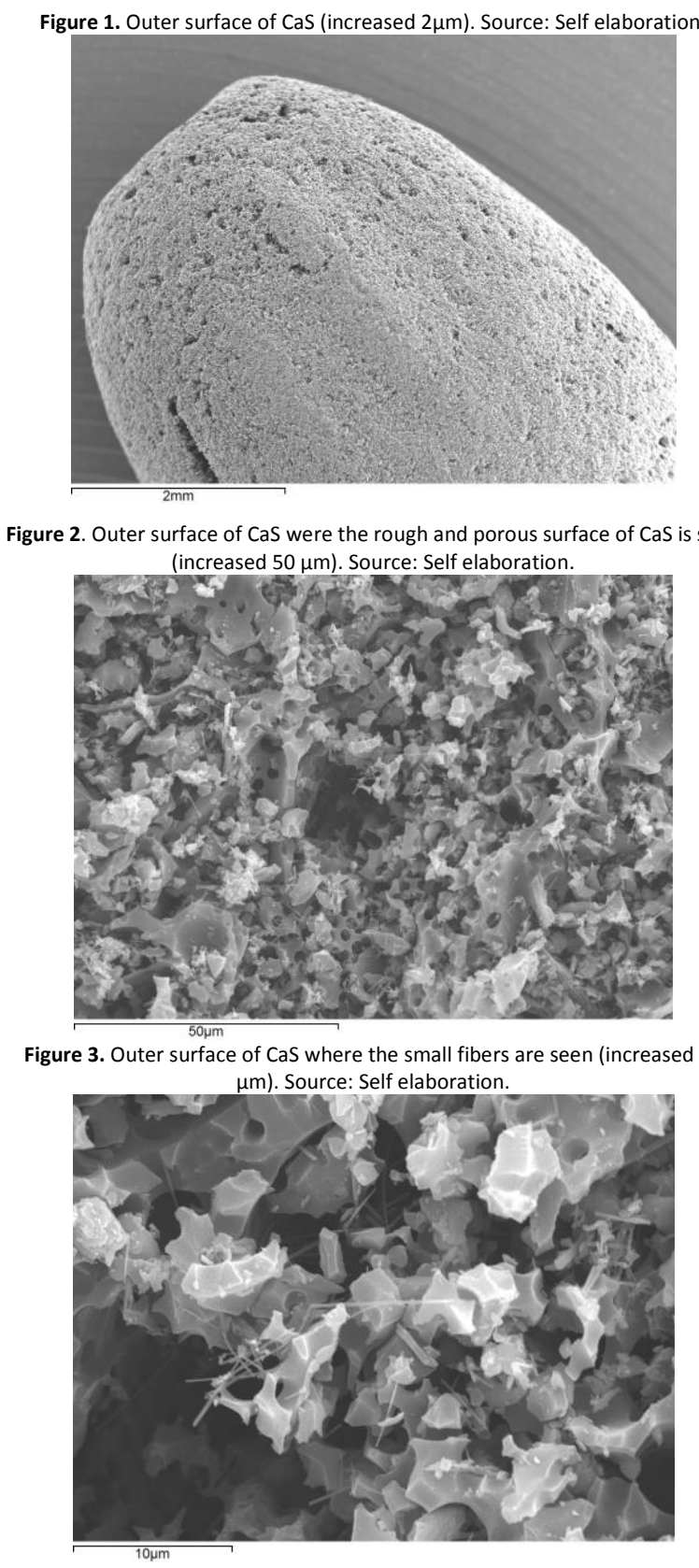

The thermogravimetric analysis of the three types of olive stones, showed that for the NoS and SCr samples in a nitrogen environment (Figure 1), about a third of their weight was lost from 600 으, inorganic matter -- i.e. carbon-.

However, as shown in Figure 2, in an oxygen environment, carbon starts combining from $600{ }^{\circ} \mathrm{C}$.

These activated carbons are highly crystalline and absorbent materials and are characterized by a large number of micro pores (porosities less than $1 \mathrm{~nm}$ of radio). One gram of activated carbon, due to its high micro porosity, may have a surface of $500 \mathrm{~m}^{2}$ or more.

Figure 4 shows the matter and humidity lost during the test: humidity (7.63\%); organic matter (64.62\%) and inorganic matter (27.75\%). 


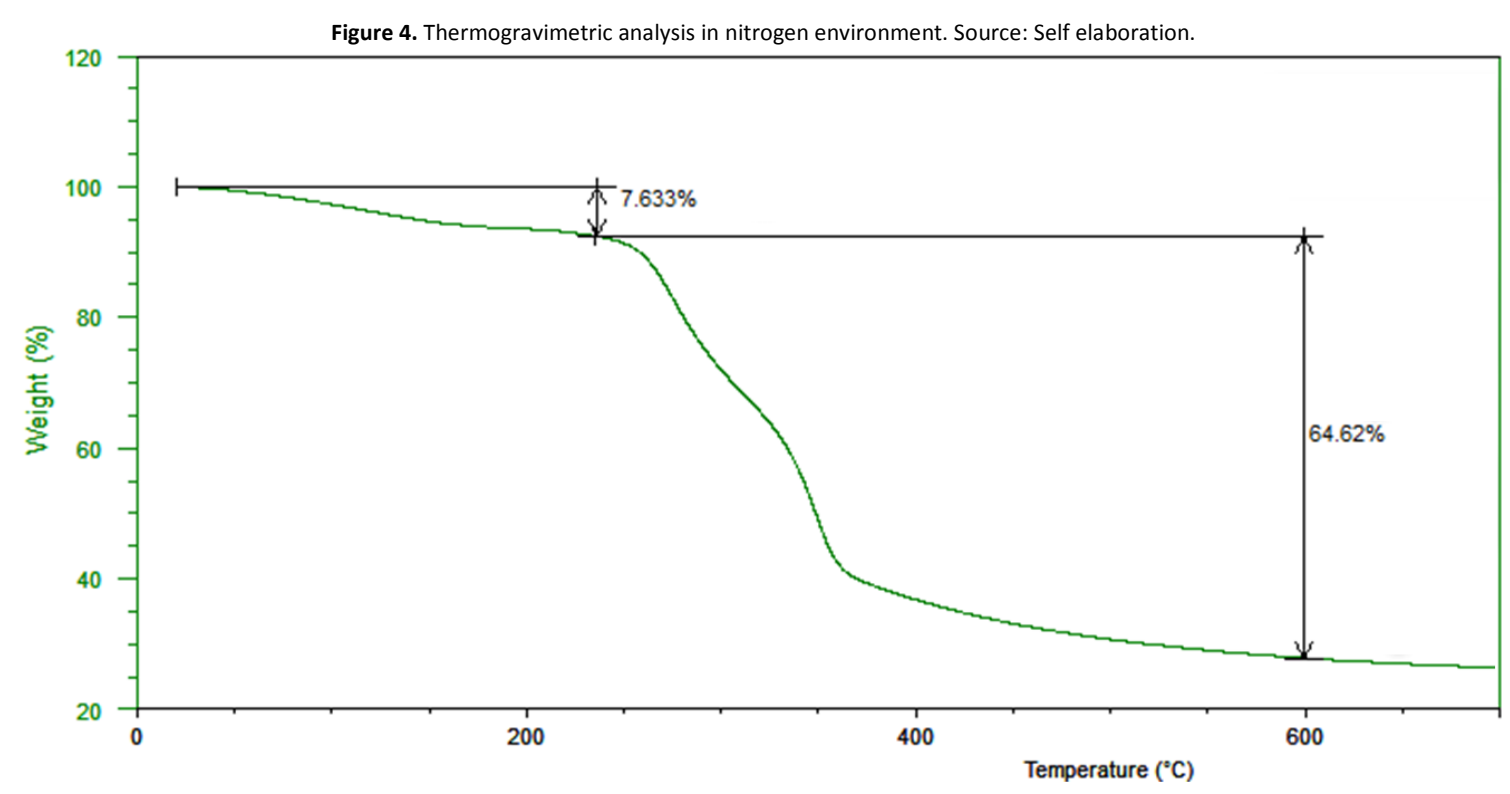

Figure 5 shows the losses -during the test- of humidity (6.85\%); Carbon (71.06\%); and the combination of carbon with oxygen and the ashes (22.08\%).

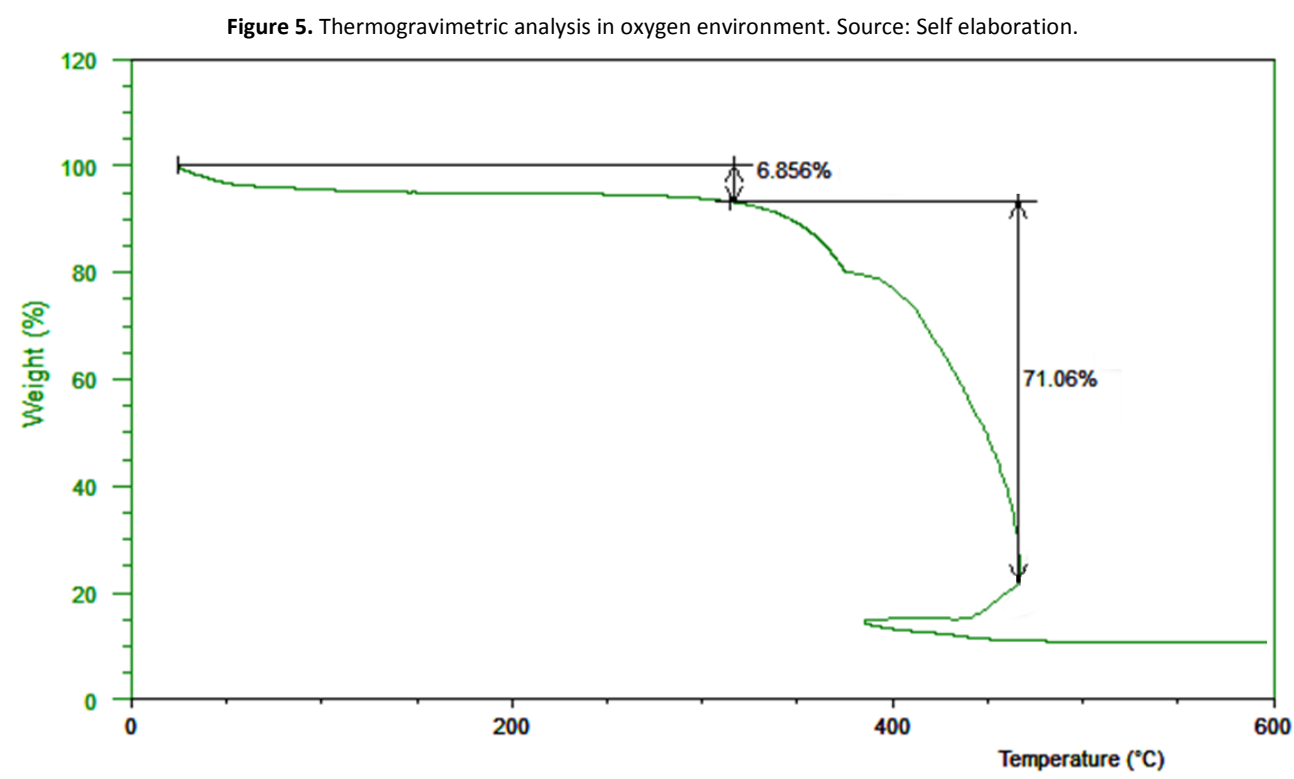

A variation in the weight of the sample was observed when $600^{\circ} \mathrm{C}$ was reached, due to the combination of carbon with oxygen. Thus, the amount of organic and inorganic matter in olive stones was determined.

\section{Lightweight mortars}

The first set of mortars that were made, replacing all the sand by olive stones, had a very dry consistency, especially mortars made with $\mathrm{SCr}$ and NoS olive stones. Also, the particle size distribution was not obtained and the mechanical strength was zero. However, if the expanded clay is replaced by calcined olive stones the values obtained in the compressive strength test -after 7 and 28 days - were higher than the $12 \mathrm{MPa}$ obtained with the reference (Figure 6). Thus, only mortars with calcined olive stones were analysed. 


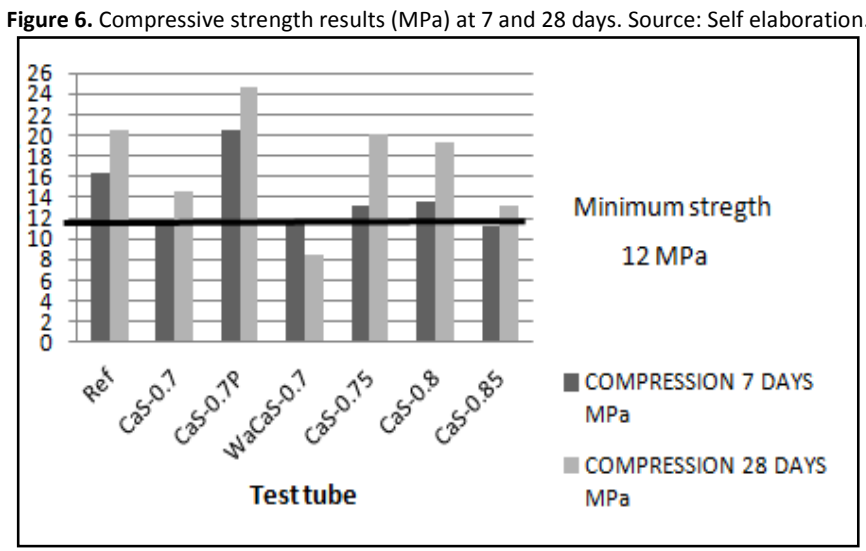

It is also observed that when adding more water ( 0.75 and 0.8 ), higher strength mortars are obtained, because of the important porosity of the olive stones. If the plasticity of the mortar is improved by adding a plasticizer, the compressive strength exceeds the one obtained with the reference (Figure 6). In this sense, including plasticizers in mortars increases the strength at 7 days, surpassing even the values achieved by the reference specimens at 28 days by around $20 \%$. Moreover, when olive stones are previously washed the lowest mechanical strengths are obtained, not solving the problem with the fines. Therefore further analysis should be done dealing with this issue.

According to the bulk densities (Figure 7), all specimens achieved densities below the reference $\left(1500 \mathrm{~kg} / \mathrm{m}^{3}\right) . \mathrm{ln}$ particular, the sample containing the plasticizer achieved the lowest values of density, 30\% lower than the reference, about $1000 \mathrm{~kg} / \mathrm{m}^{3}$.

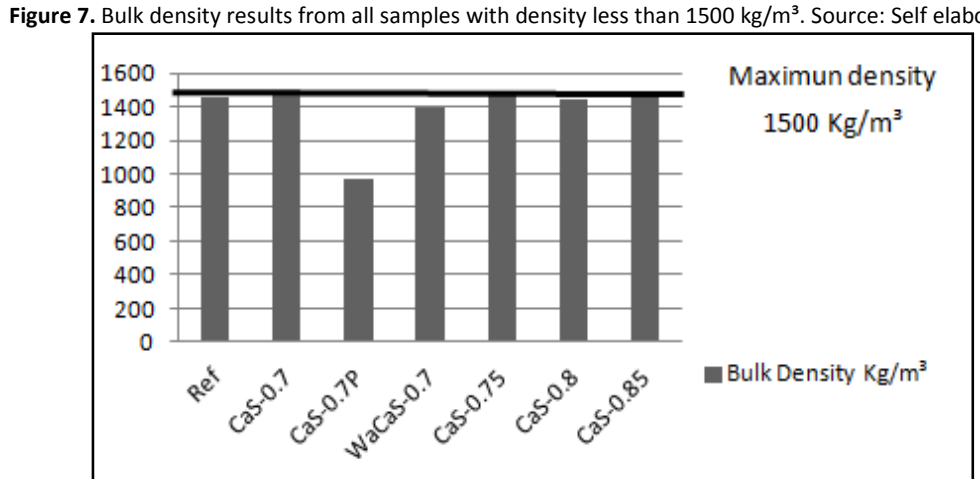

In order to analyze the adhesion between the mortar and the CaS olive stone, a visual analysis with a scanning electron microscope was conducted in the sample of the best compound CaS-0.7P. As shown in Figure 8, the cement enters the holes, allowing a physical adhesion. It is observed that CaS did not separate from the mortar, showing a fracture in the same plane as the mortar specimen. Besides this, due to the mixing of the mortar, part of the CaS olive stones were crushed and several pieces of CaS olive stones could be seen in the mortar specimen.

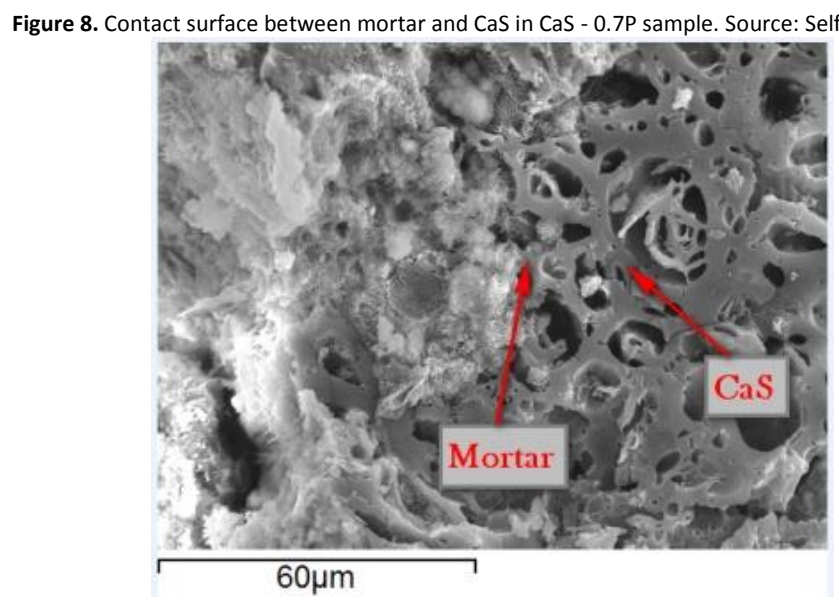


After the analysis of the three different olive stones wastes it can conclude that it is only viable to substitute expanded clay by calcined olive stones in the manufacture of lightweight mortars.

Thus, olive stones need a previous pyrolysis process treatment to be used as aggregate in cement mortars. Pyrolysis treatment requires 2.5 times less temperature than the production of the expanded clay mortars. Thus, this new mortars have less environmental-impact compared to the ones with lightened expanded clay.

If a plasticizer was added to these mortars, in order to improve its workability and consistency, compressive strength values may get $20 \%$ greater than those obtained in lightened mortars with expanded clay.

Clean the olive stones as in the compound WaCaS-0.7, do not improve the characteristics of the mortars. In fact, it had the worst mechanical strength results.

Furthermore, lightweight mortars produced with calcined olive stones, can reach densities up to $30 \%$ less than those obtained in lightened mortars with expanded clay.

Arce, X. (1997). Hormigones Livianos (Tesis doctoral) Facultad de Ingeniería en Ciencias de la Tierra, Escuela Superior Politécnica del Litoral, Guayaquil, Ecuador.

Del Río, M., Santa Cruz, J., \& Gonzalez, M. (2005). Morteros aligerados con arcilla expandida: Influencia de la granulometría y la adición de fibras de vidrio AR en el comportamiento mecánico. Informes de la Construcción, 57 (497), 40-46.

European Commission, Directorate-General for Agriculture and Rural Development. (2012). Economic analysis of the olive sector. Retrieved from https://ec.europa.eu/agriculture/olive-oil/economic-analysis_en.pdf

Fernández-Bolaños, J., Rodríguez, G., Rodríguez, R., Guillén, R., \& Jiménez, A. (2006). Potential use of olive by-products. Extraction of interesting organic compounds from olive oil waste. Grasas y aceites, 57(1), 95-106.

Ministerio de Agricultura y Pesca, Alimentación y Medioambiente. (2015). Las exportaciones del sector agroalimentario. España. Retrieved from http://www.mapama.gob.es/es/prensa/150330\%20Exportacion\%20agroalimentaria\%20Espana_tcm7-368934_noticia.pdf

Ministerio de Agricultura y Pesca, Alimentación y Medioambiente. (2014). Informe anual de la Industria alimentaria española periodo $2014-2015$. España. Retrieved from http://www.mapama.gob.es/es/alimentacion/temas/industria-

agroalimentaria/_informeanualindustriaalimentaria2014-2015_tcm7-421229.pdf

Muñoz, C. (2015). Propiedades físicas y durabilidad de morteros aligerados con arcilla expandida y agregados con áridos reciclados (Tesis doctoral). Universidad de Burgos, España.

Shafigh, P., Jumaat, M., Mahmud, H., \& Hamid, A. (2012). Lightweight concrete made from crushed oil palm shell: Tensile strength and effect of initial curing on compressive strength. Construction and Building Material, 27, 252-258.

Valdez, L. \& Suarez, G. (2010) Hormigones Livianos. (Tesina de Grado). Escuela Superior. Politécnica del Litoral, Guayaquil, Ecuador.

Weber, A. (2017). Technical Guide. Retrieved from https://es.scribd.com/document/140257865/Weber-Guia-Tecnica-Arlita-Leca 2017 